\title{
Estimation of dry matter intake by ewes at pasture, using the $n$-alkanes method
}

\author{
G Béchet, A Kerkeb, M Petit, M Thériez
}

\section{INRA, Laboratoire Adaptation des Herbivores aux Milieux, Theix, 63122 Saint-Genès-Champanelle, France}

The grass intake by ewes on a rotational grazing system was estimated using $\mathrm{C} 33$ and $\mathrm{C} 32 \mathrm{n}$ alkanes as external and internal markers (RW Mayes et al, 1986).

Three groups of 3 dry and non-pregnant Limousin $\mathrm{x}$ Romanov ewes, differing in body conditions, were allowed to graze a leafy cocksfoot pasture. The mean weights and body condition scores were: $62 \mathrm{~kg}$ and 3.0 for normal ewes $(\mathrm{N})$, $52 \mathrm{~kg}$ and 2.3 for thin ewes $(T), 49 \mathrm{~kg}$ and 1.5 for very thin ewes (VT). From July 4-17, they all received a capsule containing $220 \mathrm{mg}$ of $\mathrm{C} 32$ at $9 \mathrm{am}$. From July 8 , a rectal faeces sample was collected from each animal at the same time and also a hand-collected herbage sample on the pasture. Sward heights were regularly measured and maintained at between 7 and $12 \mathrm{~cm}$, requiring a move to a new paddock on the morning of July 11 .

The herbage $\mathrm{C} 33$ concentrations decreased with time spent in each paddock, and, because of daily variations, the values obtained by linear regression on time in each paddock (fig 1), were used to estimate the dry matter intake (DMI). Similarly, faecal C33 concentrations decreased significantly $(P<0.01)$ with time spent on each paddock and were significantly lower $(P<0.01)$ for $T$ $(74.9 \pm 9.0 \mathrm{mg} / \mathrm{kg} \mathrm{DM})$ than for $\mathrm{N}(86.5 \pm 8.8$ $\mathrm{mg} / \mathrm{kg} \mathrm{DM})$ and $\mathrm{VT}(84.0 \pm 7.0 \mathrm{mg} / \mathrm{kg} \mathrm{DM})$. It must be emphasized that the VT group was previously managed separately from the other 2 groups.

There was no significant effect of time on faecal C32 concentrations for the 3 groups, and in spite of very important daily variations (Res CV > $30 \%$ ) the mean concentration was significantly higher for $N$ ewes $(P<0.01)$. These variations are the result of variation in dry matter intake, or variation in $\mathrm{C} 32$ transit in the liquid phase of the digestive content. Thus, the daily $\mathrm{C} 32$ concentrations calculated with fixed effects of 'day' and 'ewe' (SAS), are used for DMl caculation.

To account for the daily evolution of C33 concentrations in herbage and faeces, DMl were estimated each day, but given as means for the overall period, because of daily fluctuations of C32 concentrations. Mean DMl expressed in $\mathrm{g} / \mathrm{d} / \mathrm{kg}$ LW (live weight) were: $17.8 \pm 2.6,27.0 \pm 3.1$ and $38.8 \pm 7.6$, respectively, for N, T, and VT ewes; results significantly differed between $\mathrm{N}$ and $\mathrm{T}$ groups $(P<0.05)$, and between $N$ and $\mathrm{VT}$, or $\mathrm{T}$ and VT groups $(P<0.01)$.

The use of the $n$-alkane method shows, in spite of external marker fluctuations, the relation between DMI by grazing ewes and their previous nutritional deficit.

Mayes RW, Lamb CS, Colgrove PM (1986) $J$ Agric Sci Camb 107, 161-170

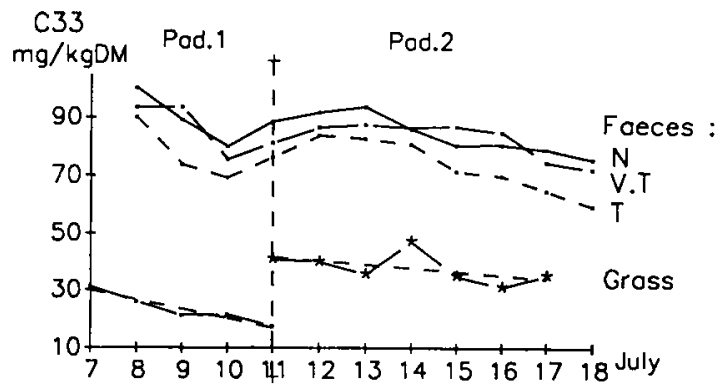

Fig 1. Grass and faeces $\mathrm{C} 33$ concentrations. 